\title{
Isolation, identification, phytochemical screening, and antibacterial activity of Aspergillus sp. MFD-01, an endophytic fungus derived from Mesua ferrea
}

\author{
Dwi Hartanti*, Risda Yunita Andestia Sinaga, Asmiyenti Djaliasrin Djalil, \\ Retno Wahyuningrum \\ Faculty of Pharmacy Universitas Muhammadiyah Purwokerto \\ Jl. Raya Dukuhwaluh PO Box 202, Kembaran, Banyumas 53182
}

Submitted: 26-05-2018

Reviewed: $10-10-2018$

Accepted: 06-11-2018

\begin{abstract}
We have successfully isolated and identified endophytic fungi from medicinal plant Mesua ferrea L. grown at Banyumas for the first time. One of those fungi was MFD-01. In this study, we report the isolation, identification, antibacterial activity, and phytochemical screening of Aspergillus sp. MFD-01. The endophytic fungus was isolated from the leaves of $M$. ferrea by subsequent inoculation on potato dextrose agar (PDA). The identification was based on its morphology and ITSDNA sequence. The antibacterial activity was determined by dilution method. The identification of compounds in ethyl acetate extract of it was conducted according to the standart phytochemical screening method. MFD-01 was identified as Aspergillus sp. MFD-01. The ethyl acetate extract of Aspergillus sp. MFD-01 inhibited the growth of both Staphylococcus aureus, and Escherichia coli. At concentration of $1000 \mathrm{ppm}$, its diameter of inhibitory zone against those bacteria was 10.53 and 11.84 $\mathrm{mm}$, respectively. The extract contained flavonoids, alkaloids, saponins, terpenoids, and tannins, which might be responsible for its antibacterial activity against both tested bacteria.
\end{abstract}

Keywords: Aspergillus, antibacterial activity, endophytic fungi, Mesua ferrea, phytochemical screening

\footnotetext{
*Corresponding author:

Dwi Hartanti

Faculty of Pharmacy Universitas Muhammadiyah Purwokerto

J1. Raya Dukuhwaluh PO Box 202, Kembaran, Banyumas, Jawa Tengah 53182

Email: dwihartanti@ump.ac.id
} 


\section{INTRODUCTION}

Endophytes, defined as those inhabit the interior of plant tissues and organs without causing harms to their hosts, have been widely studied for these last two decades (dos Banhos et al., 2014). Endophytic fungi have been known to produce various bioactive secondary metabolites, with the profound emphasis on antimicrobial ones (dos Banhos et al., 2014; Duan et al., 2016; Hartanti et al., 2016; Hussain et al., 2014; Jadson et al., 2015; Katoch et al., 2014; Liang et al., 2012; Luo et al., 2016; Zuo et al., 2014). Some of those metabolites are same or similar to those produced by their respective hosts (Kusari et al., 2012; Nicoletti and Fiorentino, 2015; Zuo et al., 2014). The selection of host plants played an important role in developing new antimicrobial agent from metabolites of endophytic fungi. Hence, the plants possessing an ethnobotanical history and producing bioactive metabolites are prioritized to be studied their endophytes further (Selim et al., 2012).

Messua ferrea is traditionally used to treat wound in Java, Indonesia (Suparman et al., 2012). It has been reported producing metabolites with antimicrobial activities (Chanda et al., 2013; Dennis, 1988; Roy et al., 2013; Verotta et al., 2004). The preeliminary study has been succeed isolating six endophytic fungi from $M$. ferrea grown in Banyumas, Indonesia (Hartanti, 2015). In our continuation studying endophytes, we are reporting isolation, identification and antimicrobial activity of Aspergillus sp. MFD-01, an endophytic fungi isolated from the leaves of M. ferrea.

\section{MATERIALS AND METHODS \\ Plant Material}

Fresh M. ferrea was collected from Banyumas, Central Java, Indonesia in February 2015. The plant material was determined at the Laboratory of Botany, Universitas Jenderal Soedirman, Purwokerto, Indonesia.

\section{METHODS}

\section{Endophytic fungi isolation}

Isolation of endophytic fungi was performed according to previously report (Hartanti, 2015). In brief, leaves of $M$. ferrea were surface sterilized with $70 \%$ ethanol and rinsed with sterile aquadest. The sterilized stems were cut aseptically and parts of the inner tissues were imprinted onto agar plates containing potato dextrose agar (PDA) medium added with powdered dried plant (15 g/l). Pure strains were obtained by repeated inoculation of growing fungi on agar plates with fresh PDA medium.

\section{Identification of Aspergillus sp. MFD-01}

Identification of the fungus was conducted by evaluating its morphology and molecular. The morphology identification was based on its macroscopic and microscopic (on light microscope with 100x magnification) characters. Molecular identification was conducted based on its rDNA sequence. The endophytic fungus is cultured in malt extract broth at room temperature for 5 days. DNA isolation was performed with following the instructions of the Nucleospin Plant II kit (Macherey-Nagel, Germany). The fungal ITS4 (5'TCCTCCGCTTATTGATATGC-3') and ITS5 (5'GGAAGTAAAAGTCGTAACAA-3') regions were amplified by PCR with the following reaction program: initial denaturation at $94^{\circ} \mathrm{C}$ for $3 \mathrm{~min}$, followed by 30 cycles of $94^{\circ} \mathrm{C}$ for $15 \mathrm{sec}$., $55^{\circ} \mathrm{C}$ for 30 sec., $72^{\circ} \mathrm{C}$ for $45 \mathrm{sec}$., and final extension at $72^{\circ} \mathrm{C}$ for 7 min (Qadri et al., 2013). The amplified products were examined by electrophoresis in $1.5 \%$ agarose gels in TAE buffer. Sequencing of the samples was performed at the sequencing facility of the Laboratory of Gene Function in Animal, Nara Institute of Science and Technology (NAIST), using the above mentioned primers. Fungal rDNA-ITS sequences was manually edited and compared with available data from GenBank databases (National Centre for Biotechnology Information website; http://www.ncbi.nlm.nih.gov/) using the BLAST program. 


\section{Cultivation of Aspergillus sp. MFD-01}

A small part of endophytic fungi Aspergillus sp. MFD-01 was transferred under sterile conditions to the potato dextrose broth medium $(250 \mathrm{~mL} / \mathrm{flask})$. The fungus was grown under static conditions at room temperature (approx. $30 \pm 3^{\circ} \mathrm{C}$ ) for 28 days. The biomass of fungi was dried and powdered in room terperature afterward (Hartanti et al., 2016).

\section{Preparation of extract of Aspergillus sp. MFD-01}

The ethyl acetate extract of fungi was prepared as a method previously reported (Hartanti et al., 2017). In brief, the powdered endophytic fungi $(34 \mathrm{~g})$ were extracted with ethyl acetate $(350 \mathrm{ml})$ using remaceration method. Each extraction was conducted for 24 hours, and the process was repeated for three times. The filtrates were collected, and concentrated in vacuo to obtain a dried extract.

\section{Antibacterial Activity Assay of Aspergillus sp. MFD-01}

Ethyl acetate extract of Aspergillus sp. MFD-01 was tested as previously described (dos Santos et al., 2015). The tested bacteria used in this study were Eschericia coli and Staphylococcus aureus, both were cultured by Laboratory of Microbiology and Genetics, Universitas Muhammadiyah Purwokerto. Ethyl acetate extract of Aspergillus sp. MFD-01 was prepared into solution in 10\% DMSO, with series of concentration of $15,31,62,125,250,500$, and $1000 \mathrm{ppm} .10 \%$ DMSO and ciprofloxacin (2000 ppm) were used as negative and positive control, respectively.

\section{Phytochemical Screening of Extract of Aspergillus sp. MFD-01}

The group of secondary metabolites (flavonoids, alkaloids, saponins, terpenoids, and tannins) in ethyl acecate extract of leaves of $M$. ferrea was analyzed with standard phytochemical screening reported elsewhere (Dior et al., 2017; Gama et al., 2014).

\section{Data Analysis}

Means separation of diameter of inhibitory zone of each concentration of extracts of endophytic fungi against tested bacteria was accomplished by Kruskal Wallis' multiple range tests. Significance was evaluated at $\mathrm{p}<0.05$. Statistical analysis was conducted by the general procedures of SPSS Statistics v.13 (SPSS Inc.).

\section{RESULT AND DISCUSSION}

MFD-01 on PDA exhibited a black with white perifer colony. The surface of the colony was powdery. Zonation of the fungus was observed on day-14 while there was no radial line observed. The microscopic observation of MFD-01 showed globose conidial heads. Conidiophores are smoothwalled. Conidial heads are biseriate with the phialides. Conidia are globse. Hyphae were septa divided and branched (Figure 1).

The data obtained from morphology of the fungi alone was not sufficient to identify it. The morphological approaches to fungal identification may not always perform well for lower-level classifications due to some limitations. A more powerful identification using DNA barcoding is suggested (Raja et al., 2017). Hence, we performed sequence-based identification of fungi using the ITS region of rDNA to ensure the identity of MFD-01. Identification was performed using BLASTN 2.8.0 (query ID: lcl|Query_187207). The analysis of the nucleotides of ITS sequences indicated that MFD-01 possessing similarity with those of some Aspergillus spp. (Table I). Hence, MFD-01 was identified as Aspergillus sp. MFD-01. 


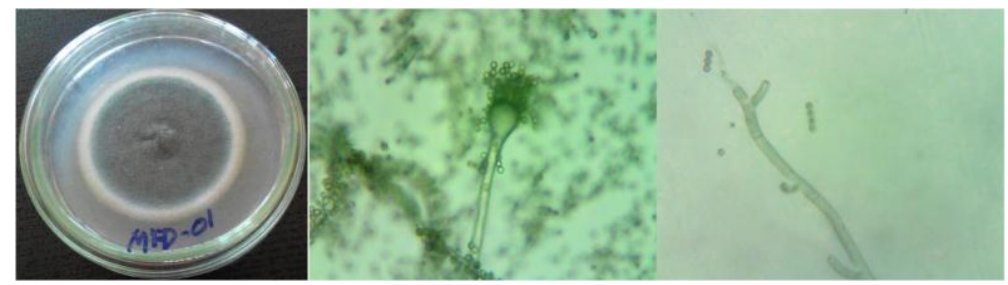

Figure 1. Morphology of MFD-01

Table I. Fungi with the most similar sequences from Genbank based on BLASTN search

\begin{tabular}{lccc}
\hline \multicolumn{1}{c}{ Fungi name } & $\begin{array}{c}\text { GenBank accession } \\
\text { numbers }\end{array}$ & $\begin{array}{c}\text { Query coverage } \\
(\mathbf{\%})\end{array}$ & $\begin{array}{c}\text { Identity } \\
(\mathbf{\%})\end{array}$ \\
\hline Aspergillus flavus clone & MH270610.1 & 89 & 94 \\
ISOJ25 & & & \\
A. versicolor clone ISOJ24 & MF164542.1 & 89 & 94 \\
A. sydowii strain ND104 & MF164494.1 & 89 & 94 \\
Aspergillus sp. isolate SLS01 & MF169502.1 & 89 & 94 \\
A. sydowii strain DJ515-2 & MF359934.1 & 89 & 94 \\
\hline
\end{tabular}

The ethyl acetate extract of of Aspergillus sp. MFD-01 exhibited the antibacterial activity against both tested bacteria (Table II). The extract at higher concentrations (250 ppm and above) inhibited the growth of $E$. coli, shown by a significant difference between those samples and negative control (DMSO) in Kruskal Wallis' test. The activity of the extract was dose dependent that in concentration of $1000 \mathrm{ppm}$ gave the highest inhibition with the diameter of $10.53 \mathrm{~mm}$. Somehow the activity of the extract was not comparable to that of Ciprofloxacin, the positive control used in this study. The antibacterial activity of ethyl acetate extract of Aspergillus sp. MFD-01 against S. aureus was similar to that against $E$. coli. It started to show bioactivity at concentration of $250 \mathrm{ppm}$, and indicated a dose dependant manner, with the maximum diameter of inhibitory zone $11.84 \mathrm{~mm}$, achieved by extract at the concentration of $1000 \mathrm{ppm}$. Its activity was also lower than that of Ciprofloxacin. Hence, Aspergillus sp. MFD-01 inhibited the growth of both Gram negative and Gram positive bacteria with the similar efficacy.

Table II. Diameter of inhibitory zones of ethyl acetate extract of Aspergillus sp. MFD-01 against E. coli and $S$. aureus

\begin{tabular}{llcc}
\hline \multicolumn{1}{c}{ Treatment } & \multicolumn{2}{c}{ Diameter of inhibitory zone $(\mathbf{m m})$ against } \\
\cline { 2 - 3 } & $\boldsymbol{E}$. coli & S. aureus \\
\hline MFD-01 & $15 \mathrm{ppm}$ & 0 & 0 \\
MFD-01 $31 \mathrm{ppm}$ & 0 & 0 \\
MFD-01 $62 \mathrm{ppm}$ & 0 & 0 \\
MFD-01 $125 \mathrm{ppm}$ & 0 & 0 \\
MFD-01 $250 \mathrm{ppm}$ & $3.75 \pm 0.70^{* \Delta}$ & $4.82 \pm 0.45^{* \Delta}$ \\
MFD-01 $500 \mathrm{ppm}$ & $5.87 \pm 0.23^{* \Delta}$ & $6.99 \pm 0.35^{* \Delta}$ \\
MFD-01 $1000 \mathrm{ppm}$ & $10.53 \pm 0.73^{* \Delta}$ & $11.84 \pm 0.30^{* \Delta}$ \\
Ciprofloxacin & $18.86 \pm 1.10^{*}$ & $19.61 \pm 1.23^{*}$ \\
DMSO & 0 & 0 \\
\hline
\end{tabular}

Note: * indicated that mean value of diameter or inhibitory zone $(\mathrm{n}=3)$ was significantly different from that of negative control; ${ }^{\Delta}$ indicated that mean value of diameter or inhibitory zone $(n=3)$ was significantly different from that of positive control; analysis was conducted at level of confidence of 0.95 
The antimicrobial activity of endophytic Aspergillus sp. has been recognized and reported elsewhere. For example, Aspergillus sp. xy02 derived from a Thai mangrove Xylocarpus moluccensis produced 12 phenolic bisabolane sesquiterpenoids, which 7 of them displayed moderate inhibitory activities against Staphylococcus aureus ATCC 25923 (Wang et al., 2018). Another study reported Aspergillus sp. IFB-YXS, an endophytic fungus residing in the apparently healthy leave of Ginkgo biloba L., also producing xanthoascin that was significantly inhibited the growth of the Clavibacter michiganense subsp. Sepedonicus (Zhang et al., 2015). The antimicrobial activity was also exhibited by Aspergillus sp. isolated from Justicia adathoda (Prabavathy and Nachiya, 2012), Aspergillus sp. of Eucommia ulmoides (Hongchi Zhang et al., 2014), Aspergillus fumigatus D derived from Edgeworthia chrysantha (Huawei Zhang et al., 2014), and Aspergillus terreus-F7, an endophytic fungus from Hyptis suaveolens (L.) Poit (da Silva et al., 2017)

The phytochemical screening test showed that the ethyl acetate extract of Aspergillus sp. MFD-01 contained flavonoids, terpenoids, alkaloids, tannins, and saponins (Table III). Those compounds might be responsible for the antibacterial activity of Aspergillus sp. MFD-01 against E. coli and $S$. aureus. Flavonoids and tannins as phenolic compounds have been known for their antimicrobial activities (Sari et al., 2015; Yakhlef et al., 2018). Phenolic bisabolane sesquiterpenoids produced by Aspergillus sp. xy02 are terpenoids, and some of them possessing antibacterial activity against $S$. aureus with $\mathrm{IC}_{50}$ values ranging from 31.5 to $41.9 \mu \mathrm{M}$ (Wang et al., 2018).

Table III. The results of phytochemical screening

\begin{tabular}{|c|c|c|c|c|}
\hline Constituents & Reagents & Positive results & Observed results & Conclusions \\
\hline Flavonoids & $\mathrm{Mg}-\mathrm{HCl}$ & $\begin{array}{l}\text { formation of orange } \\
\text { color }\end{array}$ & orange hue was observed & positive \\
\hline Terpenoids & $\mathrm{H}_{2} \mathrm{SO}_{4}$ & $\begin{array}{l}\text { formation of red color in } \\
\text { organic layer }\end{array}$ & $\begin{array}{l}\text { red hue in organic layer was } \\
\text { observed }\end{array}$ & positive \\
\hline Alkaloids & Mayer & $\begin{array}{l}\text { formation of white } \\
\text { precipitate }\end{array}$ & white precipitate was formed & positive \\
\hline Tannins & $\mathrm{FeCL}_{3}$ & the color was changed & $\begin{array}{l}\text { the color was changed from } \\
\text { yellow to reddish orange }\end{array}$ & positive \\
\hline Saponins & 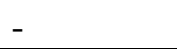 & formation of stable foam & stable foam was formed & positive \\
\hline
\end{tabular}

\section{CONCLUSION}

Aspergillus sp. MFD-01 has successfully isolated from leaves of M. ferrea. Its identity was established by morphology characteristic and ITS4 rDNA sequences. The ethyl acetate extract of Aspergillus sp. MFD-01 inhibited the growth of both Staphylococcus aureus and Escherichia coli. It contained flavonoids, alkaloids, saponins, terpenoids, and tannins that might be responsible for its antibacterial activity.

\section{ACKNOWLEDGEMENT}

The authors acknowledge the Universitas Muhammadiyah Purwokerto for financial support and Prof. Masashi Kawaichi for his kindness enabling the experiment conducted in Laboratory of Gene Function in Animals, Nara Institute of Science and Technology.

\section{REFERENCES}

Chanda, S., Rakholiya, K., Parekh, J., 2013. Indian medicinal herb: Antimicrobial efficacy of Mesua ferrea $L$. seed extracted in different solvents against infection causing pathogenic strains. $J$. Acute Dis. 2, 277-281.

da Silva, I.P., Brissow, E., Kellner Filho, L.C., Senabio, J., de Siqueira, K.A., Vandresen Filho, S., Damasceno, J.L., Mendes, S.A., Tavares, D.C., Magalhães, L.G., Junior, P.A.S., Januário, A.H., Soares, M.A., 2017. Bioactive compounds of Aspergillus terreus-F7, an endophytic fungus from 
Hyptis suaveolens (L.) Poit. World J. Microbiol. Biotechnol. 33, 1-10.

Dennis, T.J., Kumar, K.A., Srimannarayana, G., 1988. A new cyclo hexadione from Mesua ferrea. Phytochemistry 27, 2325-2327.

Dior, A., Patrick, V., Bassene, E., Nicolaas, J., 2017. Phytochemical screening, antimicrobial and cytotoxicity studies of ethanol leaf extract of Aphania senegalensis (Sapindaceae ). African J. Tradit. Compliment. Altern. Med. 14, 135-139.

dos Banhos, E.F., de Souza, A.Q.L., de Andrade, J.C., de Souza, A.D.L., Koolen, H.H.F., Albuquerque, P.M., 2014. Endophytic fungi from Myrcia guianensis at the Brazilian Amazon: Distribution and bioactivity. Brazilian J. Microbiol. 45, 153-161.

dos Santos, I.P., da Silva, L.C.N., da Silva, M.V., de Araújo, J.M., Cavalcanti, M. da S., Lima, V.L. de M., 2015, Antibacterial activity of endophytic fungi from leaves of Indigofera suffruticosa Miller (Fabaceae). Front. Microbiol. 6, 1-7.

Duan, R., Zhou, H., Yang, Y., Li, H., Dong, J., Li, X., Chen, G., Zhao, L., Ding, Z., 2016. Antimicrobial meroterpenoids from the endophytic fungus Penicillium sp. T2-8 associated with Gastrodia elata. Phytochem. Lett. 18, 197-201.

Gama, R.M. da, Guimarães, M., Abreu, L.C. de, Armando-Junior, J., 2014. Phytochemical screening and antioxidant activity of ethanol extract of Tithonia diversifolia (Hemsl) A. Gray dry flowers. Asian Pac. J. Trop. Biomed. 4, 740-742.

Hartanti, D., Novanti, D.I., Wahyuningrum, R., 2017. Isolasi, identifikasi, dan aktivitas antibakteri jamur endofit MFD-01 dari tumbuhan inang Nagasari (Mesua ferrea L.), in: Emrizal, Fadhli, H. (Eds.), Prosiding Seminar Nasional Pokjanas TOI Ke-52. Sekolah Tinggi Ilmu Farmasi Riau, Pekanbaru, 50-55.

Hartanti, D., 2015. Isolation and primary identification of endophytic fungi from Iron Wood (Mesua ferrea). Pharmacy 12, 21-24.

Hartanti, D., Supriyanto, J., Sugijanto, N.E.N., 2016. Antimicrobial activity of fractions of ethyl acetate extract of Cladosporium oxysporum, an endophytic fungus derived from Alyxia reinwardtii. J. Kefarmasian Indones. 6, 1-7.

Hussain, H., Kliche-Spory, C., Al-Harrasi, A., Al-Rawahi, A., Abbas, G., Green, I.R., Schulz, B., Krohn, K., Shah, A., 2014. Antimicrobial constituents from three endophytic fungi. Asian Pac. J. Trop. Med. 7, S224-S227.

Jadson, D.P.B., Carlos, C.F.N., Renando, N.B., Dianny, C.V. da S., Virgínia, M.S., Eliane, B.S.-N., Bruno, S.G., Laura, M.P., Cristina, M.S.-M., 2015. Endophytic fungi from medicinal plant Bauhinia forficata: Diversity and biotechnological potential. Brazilian J. Microbiol. 57, 49-57.

Katoch, M., Singh, G., Sharma, S., Gupta, N., Sangwan, P.L., Saxena, A.K., 2014. Cytotoxic and antimicrobial activities of endophytic fungi isolated from Bacopa monnieri (L.) Pennell (Scrophulariaceae). BMC Complement. Altern. Med. 14, 52.

Kusari, S., Hertweck, C., Spiteller, M., 2012. Chemical ecology of endophytic fungi: Origins of secondary metabolites. Chem. Biol. 19, 792-798.

Liang, H., Xing, Y., Chen, J., Zhang, D., Guo, S., Wang, C., 2012. Antimicrobial activities of endophytic fungi isolated from Ophiopogon japonicus (Liliaceae). BMC Complement. Altern. Med. 12, 238.

Luo, Y.-F., Zhang, M., Dai, J.-G., Pedpradab, P., Wang, W.-J., Wu, J., 2016. Cytochalasins from mangrove endophytic fungi Phomopsis spp. xy21 and xy22. Phytochem. Lett. 17, 162-166.

Nicoletti, R., Fiorentino, A., 2015. Plant bioactive metabolites and drugs produced by endophytic fungi of Spermatophyta. Agriculture 5, 918-970.

Prabavathy, D., Nachiya, C.V., 2012. Study on the antimicrobial activity of Aspergillus sp. isolated from Justicia adathoda. Indian J. Sci. Technol. 5, 3317-3320.

Qadri, M., Johri, S., Shah, B.A., Khajuria, A., Sidiq, T., Lattoo, S.K., 2013. Identification and bioactive potential of endophytic fungi isolated from selected plants of the Western Himalayas.

Pharmaciana Vol. 8, No. 2, Nov 2018, Page. 331 - 338 
Springer Plus 2, 1-14.

Raja, H.A., Miller, A.N., Pearce, C.J., Oberlies, N.H., 2017. Fungal identification using molecular tools: A primer for the natural products research community. J. Nat. Prod. 80, 756-770.

Roy, S.K., Kumari, N., Pahwa, S., Agrahari, U.C., Bhutani, K.K., Jachak, S.M., Nandanwar, H., 2013. NorA efflux pump inhibitory activity of coumarins from Mesua ferrea. Fitoterapia 90, 140-150.

Sari, P.P., Rita, S.W., Puspawati, M.N., 2015. Identifikasi dan uji aktivitas senyawa tanin dari ekstrak daun Trembesi (Samanea saman (Jacq.) Merr) sebagai antibakteri Escherichia coli. J. Kim. 9, $27-34$.

Selim, K.A., El-Beih, A.A., Abdel-Rahman, T., El-Diwany, A.I., 2012. Biology of endophytic fungi. Curr. Res. Environ. Appl. Mycol. 2, 31-82.

Suparman, S., Diniatik, D., Kusumaningrum, D., Yulianto, Y., 2012. Studi etnobotani tumbuhan sub kelas Rosidae dan penggunaannya sebagai obat tradisional di Kecamatn Baturraden Kabupaten Banyumas. Pharmacy 8, 1-8.

Verotta, L., Lovaglio, E., Vidari, G., Finzi, P.V., Neri, M.G., Raimondi, A., Parapini, S., Taramelli, D., Riva, A., Bombardelli, E., 2004. 4-Alkyl- and 4-phenylcoumarins from Mesua ferrea as promising multidrug resistant antibacterials. Phytochemistry 65, 2867-2879.

Wang, P., Yu, J.-H., Zhu, K., Wang, Y., Cheng, Z.-Q., Jiang, C.-S., Dai, J.-G., Wu, J., Zhang, H., 2018. Phenolic bisabolane sesquiterpenoids from a Thai mangrove endophytic fungus, Aspergillus sp. xy02. Fitoterapia in press.

Yakhlef, W., Arhab, R., Romero, C., Brenes, M., Castro, A. de, Medina, E., 2018. Phenolic composition and antimicrobial activity of Algerian olive products and by-products. LWT - Food Sci. Technol. 93, 323-328.

Zhang, H., Liu, R., Zhou, F., Wang, R., 2014. Antimicrobial matabolites from the endophytic fungus Aspergillus sp. of Eucommia ulmoides. Chem. Nat. Compd. 50, 454-455.

Zhang, H., Ruan, C., Bai, X., Wang, H., Chen, J., 2014. Heterocyclic alkaloids as antimicrobial agents of Aspergillus fumigatus D endophytic on Edgeworthia chrysantha. Chem. Nat. Compd. 54, 411-414.

Zhang, W., Wei, W., Shi, J., Chen, C., Zhao, G., Jiao, R., Tan, R., 2015. Natural phenolic metabolites from endophytic Aspergillus sp. IFB-YXS with antimicrobial activity. Bioorg. Med. Chem. Lett. 25, 2698-2701.

Zuo, W.-J., Jin, P.-F., Dong, W.-H., Dai, H.-F., Mei, W.-L., 2014. Metabolites from the endophytic fungus HP-1 of Chinese eaglewood. Chin. J. Nat. Med. 12, 151-153. 
